\title{
The effect of social networking sites and absorptive capacity on SMES' innovation performance
}

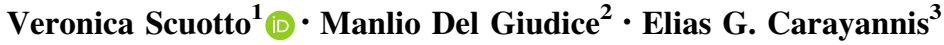

Published online: 15 November 2016

(C) The Author(s) 2016. This article is published with open access at Springerlink.com

\begin{abstract}
The combination of knowledge and innovation has become a cornerstone among knowledge and labour intensive enterprises. A growing number of enterprises are defined as knowledge intensive entrepreneurship ventures that have been widely studied in relation to their eco-system. However only few research have addressed this phenomenon to enterprises digital eco-system by adopting mainly a qualitatively approach. We point out that the relevance of the digital eco-system focusing on the role of social networking sites in relationship to innovation and knowledge. The use of social networking sites can provide a wealth of information about individuals and their networks, which can be utilised for various business purposes. It enables enterprises to create online communities and share user-created content. Within this context, enterprises actively interact with external actors such as customers, public institutions, and other businesses to acquire and absorb external knowledge, and then generate innovation. To gain insights from the global economy, 215 small to medium enterprises from different sets of global enterprises, both knowledgeintensive (e.g. management consulting, marketing and advertising, ICT and related services, legal and technical services) and labour-intensive (such as high tech and electronics, food and beverage, and consumer durables), were analysed. Via the Partial Least SquarePath Modelling the relationships between social networking sites, absorptive capacity, and innovation performance were measured. Therefore, recommendations are proffered as to what small-medium enterprises should do in order to enhance their innovativeness. The research ends with conclusions and implications to both scholars and practitioners.
\end{abstract}

Keywords Knowledge intensive entrepreneurship · Absorptive capacity · Social networking sites $\cdot$ Innovation $\cdot$ SMEs

Veronica Scuotto

veronica.scuotto@uws.ac.uk

University of West of Scotland, Paisley, UK

2 University of Rome "Link Campus", Rome, Italy

3 George Washington University, Washington, DC, USA 


\section{JEL Classification M2}

\section{Introduction}

The proliferation of widespread access to internet, microblogging, social networking sites (SNSs) has changed the way in which entrepreneurs develop innovation. The growing use of social networking sites such as Blog, Facebook, Twitter, YouTube among others along the embeddedness of external knowledge supports entrepreneurial journey (PalaciosMarques et al. 2015a, b). Entrepreneurs discover new ways of combining internal and external knowledge exploiting market opportunities (McKelvey and Lassen 2013). In turns, enterprises become more knowledge intensive enhancing their creative process and continually changing their existing routine. Such enterprises are more focused on making a balance between knowledge and innovation which as their competitive asset. They are more dynamic and active in exploit opportunities in order to make up innovations using intensively knowledge (Malerba 2010). This phenomenon reflects on the knowledge intensive entrepreneurship framework that emphasize the propensity of entrepreneurs to cope with uncertainty and generate changes or creative destructions (Schumpeter 1934).

However as recently entrepreneurs race to create innovative ideas, there is an upward awareness that this cannot be done without the involvement of digital tools (Scuotto 2014, 2015; Scuotto et al. 2016a, b; Bharati et al. 2013; Dholakia and Durham 2010; Kozinets et al. 2010). That is because enterprises need to intensify their capacity to absorb external knowledge mainly from the virtual environment and combine it with the internal knowledge (Cohen and Levinthal 1990). Management scholars recognised such ability as absorptive capacity, which is likely to support enterprises in acquiring knowledge from the external environment (March and Herbert 1958; Zahra and George 2002; Coccia 2008). Therefore enterprises tend to develop innovative ideas without conducting in-house research but generating new knowledge through a dynamic and cooperative approach (Leyden and Link 2015). The ongoing combination of discovering and exploiting intensively and actively drives entrepreneurs in creating innovation within either new ventures (Malerba 2010) or established organizations (Hirsch-Kreinsen and Schwinge 2014).

In fact analysing the current role of social networking sites (SNSs) within enterprises, scholars and practitioners point out that the development of SNSs strategy accelerates and deepens enterprises' service innovation and growth by promoting specialisation within customers, suppliers, and other businesses (Bharati et al. 2013; Amy and Poston 2013). As mentioned by Stelzner (2013) $86 \%$ of entrepreneurs declare that SNSs are important for their business, $69 \%$ decide to learn more about social media platforms, and $66 \%$ plan to increase blogging activities. Stelzner (2013) also highlights three types of benefits created from the use of SNSs. The first one is to generate more exposure ( $89 \%)$; the second benefit relates to the increase in online traffic $(75 \%)$, and the last refers to lead generation $(64 \%)$. This, in turn, results in faster time to market, faster product adoption, and lower product development cost for enterprises.

However while corporate enterprises have already started to introduce SNSs in their organisational environment to improve their innovation performance, SMEs are accustomed to using these digital tools recently. SMEs are commonly recognised as effective business forms that positively influence employment generation, wealth creation, and economic growth (Soto-Acosta et al. 2015; Scuotto and Morellato 2013; Jardim-Goncalves et al. 2012; Damirchi and Rahimi 2011). In fact exploiting opportunities, SMEs make the 
attainment of an equitable and sustainable growth (Campanella et al. 2013; Del Giudice and Maggioni 2014). These enterprises are mainly labour intensive (around $43 \%$ ), establishing around $70 \%$ of employment (AUB Observatory 2014). This growth of SMEs' performances has increasingly inspired current studies in analysing the embeddedness of the new digital tools within their organizational settings (Aboelmaged 2014; Huy 2012; Lopez-Nicolas and Soto-Acosta 2010). In particular, the majority of academic scholars have focused their own research on the digital environment focusing on social networking sites as marketing tools (Berinato 2010) or on how these channels increase marketing communication effectiveness (Dholakia and Durham 2010; Kozinets et al. 2010; Trusov et al. 2009; Decarolis and Deeds 1999; McEvily and Chakravarthy 2002; Levy 2009; Pechlaner and Bachinger 2010). Although as far as we know, still little is known about how these digital tools may benefit enterprises' innovation performance as a measure of enterprises' overall innovativeness (Palacios-Marques et al. 2015a, b).

In line with the foregoing issue, the present research investigates if there is a positive relationship between social networking sites, absorptive capacity, and innovation performance. An empirical research was conducted on 215 SMEs from different sets of global enterprises, both knowledge-intensive (e.g. management consulting, marketing and advertising, ICT and related services, legal and technical services) and labour-intensive (such as high tech and electronics, food and beverage, and consumer durables), the knowledge-intensive enterprises accounting the $75 \%$ of the whole sample of enterprises selected (Amy and Poston 2013). Therefore, via Partial Least Square-Path Modelling (PLS-PM), a positive relationship between the use of SNSs and innovation performance through a high level of absorptive capacity was demonstrated.

Based on this, the study was addressed as follows. Firstly, the theoretical framework provides a contextual backdrop on the relevance of SNSs in the current global economy; moreover, it focuses on how they enhance enterprises' absorptive capacity based on the lens of knowledge-intensive entrepreneurship. Consequently, the theoretical scenario ends reporting studies on the advantage of SNSs on enterprises' innovation performance, as a measure of enterprises' innovativeness. In order to address the gap into the theoretical framework, the research design and findings were reported and discussed. Concluding remarks are offering insights supporting future innovation strategies as well as stimulating new academic research in this direction.

\section{Theoretical framework}

According to the knowledge intensive entrepreneurship prospective, existing enterprises have got a dynamic entrepreneurial spirit that leads their ability to exploit opportunities using intensively external knowledge in combination with the internal knowledge so as to introduce innovation (Audretsch et al. 2016; Hirsch-Kreinsen and Schwinge 2014). Along the intensive use of knowledge, the digital eco-system becomes more and more another competitive asset in the innovation process (Scuotto 2014, 2015; Scuotto et al. 2016a, b; Bharati et al. 2013; Dholakia and Durham 2010; Kozinets et al. 2010). In particular, in the digital eco-system a determinant role has been assumed by Social Networking Sites (SNSs) that have been changing the way to implement global business strategies. SNSs are ITbased sources (Palacios-Marques et al. 2015a, b) that "allow individuals to construct a public or semi-public profile within a bounded system, articulate a list of other users with whom they share a connection and view and traverse their list of connections and those 
made by others within the system" (Boyd and Ellison 2008: 211). SNSs include digital platforms such as Facebook as social networking, You Tube as video sharing, Pinterest as picture sharing, LinkedIn as professional networking, Blogs as weblogs, Foursquare as location-based social networking website, and Twitter as microblogging (Fisher and Reuber 2011; Schmallegger and Carson 2008). Global enterprises use all of these digital platforms in order to enhance their absorptive capacity that, as previously stated, concerns in the process of a combination between external and internal knowledge (Audretsch et al. 2014; Cohen and Levinthal 1990). In turns, the absorptive capacity enables enterprises to convert the external knowledge into new technological knowledge (Del Giudice et al. 2014). In line with this, the SNSs are likely to be a suitable environment where people can share information, collaborate, discuss common interests, and build relationships (Palacios-Marques et al. 2015a, b). Moreover, these platforms facilitate enterprises' interactions with their stakeholders such as consumers, public institutions, and other businesses (Betz et al. 2016; Carayannis 2015; Carayannis and Rakhmatullin 2014; Hvass and Munar 2012). Kaplan and Haenlein (2010) declare that SNSs are recognised to be as a new cyber space where users generate content. In fact, enterprises create brand communities in the form of brand fan pages where it is possible to develop an interactive relationship between enterprises and their consumers by linking and commenting on the brand's posts (McAlexander et al. 2002; Muniz and O'Guinn 2001). For instance, enterprises set up a Facebook page in order to develop one to one communication with users, to personalise services, and increase brand loyalty and reputation (Hanna et al. 2011; McAlexander et al. 2002; Muniz and O'Guinn 2001). Twitter is also a valued digital platform to promptly communicating with customers but would probably be a bad option if you cannot respond quickly (Culnan et al. 2010). With the use of SNSs, global enterprises describe and promote new products or services to potential customers with whom they co-create innovative business ideas as well (Tussyadiah and Zach 2013). Enterprises use SNSs to generate, modify, share, and discuss internet content with global customers (Kietzmann et al. 2011). Therefore, a better costumers' engagement comes from the use of SNSs. Indeed as Garretson (2008: 12) points out that "consumers increasingly use digital media not just to research products and services, but to engage the enterprises they buy from, as well as other consumers who may have valuable insights". In this way, consumers assume an active role promoting innovations (Chalkiti and Sigala 2008; Casaló et al. 2010; Kaplan and Haenlein 2010; Sigala and Chalkiti 2012). SNSs give users a voice in bringing up a new innovative idea and reduce costs of in-house research for innovation. Users' innovative ideas are converted in technological knowledge through the combination of enterprises' existing knowledge (Arts and Veugelers 2015; Cohen and Levinthal 1990; Hargadon 2003) rather than experimenting and discovering something ex nihilo. The diverse approach of the innovations has brought up several discussions, splitting up scholars in two streams: the first one considers innovations originating from an exploitation and recreation of an existing technology (Wang and Scuotto 2012; Kim 2004; Hobday 1995). While on the other side, scholars debate that innovations should derivate from an exploration approach where an invention may arise (Ahuja and Morris Lampert 2001; Rosenkopf and Nerkar 2001). Actually in line with the first stream, we assume that innovation stem from an open and collaborative approach. Such collaboration is not necessarily related only to highly qualified staff (Blackler 1995) but stakeholders surfing on the virtual environments. The virtual environment is a setting of a wide range of activities such as creative adaptation or technological leapfrogging (Hobday 1995). Hence a context where enterprises meet their global consumers in order to enhance an existing product beyond the original design parameter (Kim 2004). The online milieu contributes to the 
improvement of enterprises' innovativeness by simplifying coordinated actions and facilitating the flow on internal and external knowledge (Chalkiti and Sigala 2008; Sigala and Chalkiti 2012).

In sum, SNSs are considered as the perfect tools to influence current and potential consumers (Hanna et al. 2011) and bring up innovation (Chalkiti and Sigala 2008; Sigala and Chalkiti 2012), and also as a supportive technology that may be used, strategically or not, in any industry and in any global strategy (Porter 2001).

Therefore, since we retain that SNSs have a positive impact in enhancing enterprises' innovativeness, we hypothesize that:

H1 The use of SNSs positively influences SMEs' innovation performance.

Innovation results more from borrowing rather than from invention (March and Herbert 1958; Hussinger 2012) where the relevant asset is the knowledge (Nicotra et al. 2014; Del Giudice and Straub 2011; Carayannis et al. 2015a, b; Carayannis and Alexander 1999). Given the chance to spread out information by virtual spaces, the intensive use of knowledge improves enterprises' knowledge capacity (Shih et al. 2010) and, in turns, their innovation performance (Del Giudice et al. 2014). An entrepreneur becomes more dynamic, playing an active role in interfacing between his own organizational setting and external eco-system (Malerba 2010). Consequently enterprises are more knowledge intensive breaking out their routines and racing their competitive market with innovative ideas (McKelvey and Lassen 2013). In this scenario, knowledge has been considered as a flow (Weinberger 2007; Decarolis and Deeds 1999; McEvily and Chakravarthy 2002; Levy 2009; Pechlaner and Bachinger 2010) that moves smoothly among SNSs and to be absorbed within an enterprise. As expressed above, Cohen and Levinthal define this capacity as an enterprise's ability to convert an external knowledge into an innovation. Absorptive capacity needs both a stock of existing and new knowledge (Liao and Yu 2013; Roberts et al. 2012). So absorbing external knowledge, enterprises generate innovations reducing their costs of in-house research and minimizing their investment risk (Del Giudice et al. 2014; Chesbrough 2011; Kaplan and Haenlein 2010; Metters and Walton 2007).

From a theoretical point of view, management scholars identified two categories of absorptive capacity (Cohen and Levinthal 1990; Lane and Lubatkin 1998): (1) Potential absorptive capacity (Fosfuri and Tribó 2008) and (2) realised absorptive capacity (Jansen et al. 2005). The first one is characterised by knowledge acquisition and assimilation, where knowledge acquisition is the capability of enterprise to recognise, value, and acquire external knowledge, whilst knowledge assimilation is the enterprises' ability to absorb external knowledge. Realised absorptive capacity is distinguished instead by knowledge transformation and exploitation. Knowledge transformation can be defined as the ability of an enterprise to develop routines through the combination of existing knowledge and newly acquired and assimilated knowledge. Knowledge exploitation is the process through which an enterprise refines, extends, and leverages existing competences or generates new ones by acquisition and transformation of external knowledge (Zahra and George 2002). This process allows enterprises to create relational networks with their stakeholders (Ahuja 2000). By integrating implicit and explicit knowledge, enterprises' innovative capabilities are enhanced. Hence business performance relies on the ability to exploit external knowledge, and how that knowledge is used to develop new goods and services (Berghman et al. 2006; Dev et al. 2010; Gopalani and Shick 2011; Gronroos and Ravald 2011).

Concurring with the above literature review, we state that absorptive capacity as a key determinant of enterprises' innovativeness. Based on this the following hypothesis has been investigated: 
H2 Absorptive capacity positively affects SMEs' innovation performance.

On from above discussion, it can be inferred that the advantages of innovation stem from the improvement of absorptive capacity using SNSs. Many researchers stress that absorptive capacity contributes both directly (Lichtenthaler 2009) and indirectly (Lane et al. 2006) to innovation performance. According to Zahra and George (2002), absorptive capacity has a crucial role in the innovation process because an enterprise with higher absorptive capacity tends to adjust its internal organization to changes in its environment, to explore opportunities even solutions, and to exploit innovation to meet its needs as well.

Innovation has been considered as either the ability to develop products able to meet the consumers' needs or the ability to use existing technology to develop new products (Audretsch et al. 2015, 2016) or to improve existing ones (Adler and Shenhar 1990). Duncan (1972) argues that innovation is a creative strategic action involving implementation of existing ideas to generate new products or figure out a problem. Innovation is also conceived as a driver of enterprises' evolution strategy rather than as just a reaction to the external changes. It is a mean of generating new ideas. Innovation is a result of interactive relationships between suppliers, customers, other businesses, and research centres (Leyden and Link 2015; Laursen and Salter 2006; Carayannis and Alexander 1999). Mansfield (1986) suggests that the collaboration with other stakeholders enables enterprises to accelerate product time to market, product adoption, and consequently reduce product lifecycle. Briefly, innovation is performed in cooperation with external actors (Audretsch et al. 2014) and it is originated through enterprises' knowledge circulation (that is a process on inflows and outflows of knowledge) which facilitates the development of internal innovation, and even its commercialization (Nonaka and Takeuchi 1995; Chesbrough and Crowther 2006). According to Hirsch-Kreinsen and Schwinge (2014), new ventures and existing business innovate applying dynamically a new knowledge.

However despite that, for the success of an innovative enterprise, the acquisition and combination of knowledge capable of bringing together new ideas is not sufficient and a virtual network structure is required in order to support the innovation process in the long run and to make it successful enough to be deemed legitimate (Hannu et al. 2010; Scuotto 2014, 2015; Scuotto et al. 2015, 2016a, b). As well as the virtual environment results to be as a "virtuous engine of technology transfer" takes place exploiting the global knowledge intensive (Carayannis et al. 2015a, c). Therefore, the process of creating a new technological knowledge cannot be efficient without the use of SNSs and a solid absorptive capacity (Bharati et al. 2013).

Hence, absorptive capacity in conjunction with social media strategy results in the following research hypothesis:

H3 A higher level of absorptive capacity through the use of SNSs positively influences SMEs' innovation performance.

\section{Method}

From the above literature review, academic scholars (Bharati et al. 2013; Dholakia and Durham 2010; Kozinets et al. 2010; Trusov et al. 2009) have focused their research on SNSs as marketing tools (Berinato 2010) or on how these channels increase marketing communication effectiveness (Dholakia and Durham 2010; Kozinets et al. 2010; Trusov et al. 2009). Little is known, however, about how they may benefit innovation performance 
of an enterprise (Palacios-Marques et al. 2015a, b). No major studies have analysed the relationship between absorptive capacity, SNSs, and innovation performance under the point of view of knowledge intensive entrepreneurship within global enterprises.

We retained that through an intensive use of knowledge- either internal or externalenterprises are dynamically proactive in generating innovation (Audretsch et al. 2016; Hirsch-Kreinsen and Schwinge 2014; Tussyadiah and Zach 2013; Malerba 2010). In line with this, via Partial Least Square-Path Modelling (PLS-PM) we assessed if there is a positive relationship between the use of SNSs and enterprises' innovation performance due to a solid absorptive capacity in 215 worldwide SMEs.

Data were collected through a database of Kalypso consultancy enterprise: 500 knowledge-intensive and labour-intensive global SMEs (the first ones accounting the $75 \%$ of the whole sample) were selected in reference to the following three control variables:

1. Enterprises' size is a one of the most relevant factor of innovation performance. As established in innovation literature, enterprises' size could be considered a proxy for slack resource and infrastructure that improve enterprises' innovativeness (Rogers 2003).

2. Annual Revenue is a factor that represents both enterprises' ability to survive on worldwide markets and to invest in R\&D activities (Utterback 1974).

3. The use of SNSs as part of enterprises' global strategy that enables knowledge creation and acquisition so as to turn it into product or service (Culnan et al. 2010).

Obtaining information on enterprises' size and annual revenue through the database, we proceed to approach enterprises by email in order to select who were using social networking sites. When no responses were received by email, SMEs were approached by phone. Hence after 6 weeks, we received responses from 320 SMES. For each SMEs, a survey designated in english and composed of 20 questions along a brief introduction of the research purpose were administrated by email. The survey was completed from a respondent of each enterprise, holding the position as CEO or founder as considered the main enterprises' decision maker. The received responses were 215 , giving back a response rate of $67 \%$, considered statistically significance.

The survey was structured out using a funnelling technique (Bryman 2015) where at the beginning to each respondent was asked to provide information of some ancillary items such as gender, job position, industry, etc. and then more focused questions were stated. For example, the respondents were asked to indicate the value of the use of social networks sites in innovation process using the five-point Likert scale (1932), where the "code 1" meant strongly agree and "code 5" meant strongly disagree. Moreover, in order to minimize the response bias, this type of a question was mixed with others composed of a range of inclusive definitions on above statements to be selected.

The questions were divided in three measures such as (1) Innovation performance; (2) absorptive capacity, and (3) social networking sites (Table 1).

To assess these data, the partial least square-path modelling (PLS-PM) was applied. The PLS-PM is a method that fits with this exploratory research because it is focused on prediction data (Lohmöller 1989; Bharati et al. 2013). The PLS-PM is characterised by both a factor model and a path model. Factor model enables the researcher to evaluate items or manifest variables in relation to their own latent variables or factors. Path analysis (Weston et al. 2008), on the other hand, measures the positive or negative connection among LVs. Unlike traditional multivariate procedure, PLS provides explicit and estimated error of variance parameters (Byrne 2013), and is able to examine more than one regression equation/relationship at the same time. 
Table 1 Measures

\begin{tabular}{|c|c|c|}
\hline Measures & Description & Source \\
\hline $\begin{array}{l}\text { Innovation } \\
\text { performance }\end{array}$ & $\begin{array}{l}\text { It regards to the development of new } \\
\text { product or service adopting an open } \\
\text { approach. In line with this, SNSs may be } \\
\text { recognised as a new environment that } \\
\text { manages knowledge and encourages the } \\
\text { development of new ideas } \\
\text { Therefore, this measure calls for } \\
\text { Faster time to market } \\
\text { Faster to product adoption } \\
\text { Product lifecycle management }\end{array}$ & $\begin{array}{l}\text { Chesbrough (2011), Amy and Poston } \\
\text { (2013), Ku (2013), McEvily and } \\
\text { Chakravarthy (2002), Schultze and Stabell } \\
\text { (2004), Levy (2009), Hine et al. (2010) }\end{array}$ \\
\hline $\begin{array}{l}\text { Absorptive } \\
\text { capacity }\end{array}$ & $\begin{array}{l}\text { It refers to the ability of an enterprise to } \\
\text { acquire external knowledge, combine, and } \\
\text { assimilate it within the organizational } \\
\text { setting. This process enables enterprises to } \\
\text { develop less in-house research and } \\
\text { development activities. Therefore, this } \\
\text { measure calls for } \\
\text { External knowledge } \\
\text { Internal knowledge } \\
\text { R\&D activities }\end{array}$ & $\begin{array}{l}\text { Nicotra et al. (2014), Del Giudice and } \\
\text { Straub (2011), Carayannis and Alexander } \\
\text { (1999), Zahra and George (2002), Cohen } \\
\text { and Levinthal (1990), March and Herbert } \\
\text { (1958) }\end{array}$ \\
\hline $\begin{array}{l}\text { Social } \\
\text { networking } \\
\text { sites }\end{array}$ & $\begin{array}{l}\text { It is related to IT-based sources that "allow } \\
\text { individuals to construct a public or semi- } \\
\text { public profile within a bounded system, } \\
\text { articulate a list of other users with whom } \\
\text { they share a connection and view and } \\
\text { traverse their list of connections and those } \\
\text { made by others within the system". } \\
\text { Hence, this measure calls for: } \\
\text { Social communities } \\
\text { Social media platforms } \\
\text { Social media capabilities }\end{array}$ & $\begin{array}{l}\text { Boyd and Ellison (2008), Palacios-Marques } \\
\text { et al. (2015a, b), Scuotto (2014, 2015), } \\
\text { Scuotto et al. (2016a, b), Hvass and } \\
\text { Munar (2012), Kaplan and Haenlein } \\
\text { (2010) }\end{array}$ \\
\hline
\end{tabular}

\section{Findings}

From the aforementioned measures, we selected nine manifest variables that were considered as the "reflection" of the relative three latent variables (Table 2) (Tenehaus et al. 2010).

The path diagram below (Fig. 1) illustrated the hypothesised relationships among these variables, either manifest or latent. Square shapes represent manifest variables whereas the oval ones are latent variables; one-way arrows indicate the impact of exogenous LVs on endogenous ones, and of MVs on LVs.

Latent variables were categorised in exogenous and endogenous: SNSs and absorptive capacity are exogenous latent variables - they are synonymous with independent variables - that affect the relationship with innovation performance as an endogenous latent variable. Moreover, in that case, absorptive capacity was considered as either exogenous or endogenous because we retain that this variable affects innovation performance (endogenous latent variable) and is affected by SNSs (exogenous latent variable). Finally, innovation performance was measured as a dependent variable. 
Table 2 Latent and manifest variables

\begin{tabular}{ll}
\hline Latent variables & Manifest variables \\
\hline Innovation performance & Faster time to market $(\mathrm{y} 1)$ \\
& Faster to product adoption (y2) \\
& Product lifecycle management (y3) \\
Absorptive capacity & External knowledge (y4) \\
& Internal knowledge (y5) \\
& R\&D activity (y6) \\
SNSs & Social communities (y7) \\
& Social media platforms (y8) \\
& Social media capabilities (y9) \\
\hline
\end{tabular}

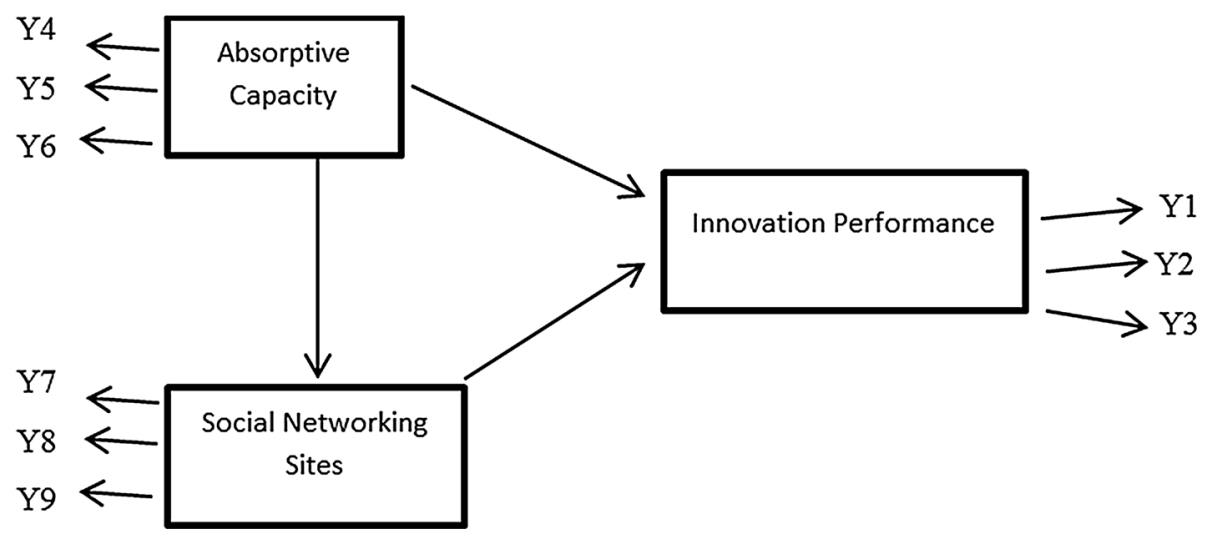

Fig. 1 Path diagram

Table 3 Cronbach's alpha reliability coefficient

\begin{tabular}{lr}
\hline Cronbach's alpha & \\
\hline Absorptive capacity & .85 \\
Innovation performance & .81 \\
SNSs & .73 \\
\hline
\end{tabular}

Using IBM-SPSS Statistics 23.0, the reliability of the block of MVs and its LV and $\mathrm{R}^{2}$ were assessed. The Cronbach's Alpha was the assessment of the reliability which was scored as $>.70$. This value indicates that there is a positive internal consistency among LVs and MVs. In details, absorptive capacity results to be scored as .85 , Innovation performance .81, and SNSs is .73 (Table 3).

Successively $\mathrm{R}^{2}$ has been estimated to verify the quantity of variance of endogenous variables in relation to exogenous variables. As emerged from the findings, the value of $R^{2}$ results as positive for both innovation performance (.88) and absorptive capacity (.71) (Table 4).

The positive reliability, relationships among LVs was measured by a path analysis. The results show that absorptive capacity (7.8) is the crucial factor to improve enterprises' innovativeness. Although the use of SNSs (6.3) seems also relevant in enhancing enterprises' innovation performance as well as their absorptive capacity (Fig. 2). 
Table $4 \mathrm{R}^{2}$

\begin{tabular}{lll}
\hline & Absorptive capacity & Innovation performance \\
\hline $\mathrm{R}^{2}$ & .71 & .88 \\
\hline
\end{tabular}

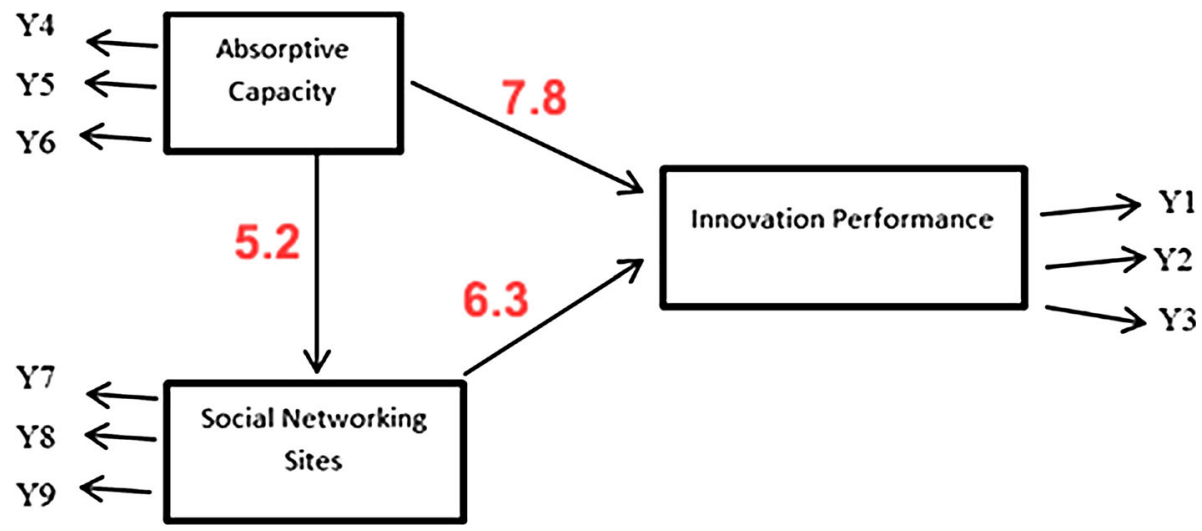

Fig. 2 Path analysis

\section{Discussion}

From the above findings, the research hypotheses were confirmed as follows:

H1 The use of SNSs positively influences SMEs' Absorptive Capacity.

The positive relationship between SNSs and absorptive capacity was registered by value 5.2 .

H2 Absorptive capacity positively affects SMEs' innovation performance.

The high impact of absorptive capacity on innovation performance was registered by value 7.8 .

H3 Enhancing enterprises' absorptive capacity through the use of SNSs strategy positively influences the SMEs' innovation performance.

Path analysis shows that innovation performance has a positive correlation with absorptive capacity (7.8) and SNSs (6.3).

Taken together, our findings showed that SMEs' absorptive capacity mainly affects their innovation performance which is related to external knowledge acquisition process (Palacios-Marques et al. 2015a, b). As stated by Cohen and Levinthal (1990), absorptive capacity enables enterprises to acquire, transfer, and assimilate external knowledge within the organisation and then generate new ideas. This process generates new technological knowledge based on user-oriented innovation. In turns, global enterprises, both knowledge and labour-intensive, enhance their innovativeness, intensifying the inflow and outflow knowledge. The continuous circulation of knowledge intensive drives enterprises' ability to identify and absorb external knowledge. Although this process is limited due to the fact that enterprises are not be able to independently evaluate the value of external knowledge (Del Giudice and Maggioni 2014; Carayannis et al. 2014a, b). The intensive use of 
knowledge relies on entrepreneurs' dynamic ability to innovate (Audretsch et al. 2016; Hirsch-Kreinsen and Schwinge 2014).

This virtuous engine of innovation takes place on SNSs that become like kind of "laboratories" where is possible to experiment new innovative ideas. As emerged from the empirical research, the use of SNSs leverages enterprises' innovation performance. The role of SNSs in enhancing both enterprises' absorptive capacity and innovation performance was confirmed by the positive $\mathrm{R}^{2}$ values (.71 relates to absorptive capacity and .88 . refers to innovation performance) as well as the path analysis (the relationship between SNSs and Innovation performance was registered by value 6.3). Moreover, also the relationship between SNSs and absorptive capacity was confirmed by the score of 5.2.

SNSs enable enterprises to create social communities shared by external stakeholders such as customers, suppliers, other enterprises, among others. These actors generate a knowledge-based flow that has been intensively using within enterprises to introduce creative destructions (Audretsch et al. 2016; McKelvey and Lassen 2013 Malerba 2010). Furthermore, they can lead structural changes, which could be done individually, as well (Campbell et al. 2015; Carayannis and Rakhmatullin 2014). In turns, enterprises can discuss their respective ideas and co-create innovations (Kaplan and Haenlein 2010). Chesbrough (2011) also points out that an enterprise develops innovations based on contents generated by users. The use of SNSs accelerates and deepens enterprises' innovativeness at a global level. Enterprises create virtual relationships with customers, suppliers, and other businesses gaining a competitive advantage (Teirlinck and Spithoven 2012). They may get to market more quickly, show faster product adoption, and lower product development costs (Amy and Poston 2013). Hence SNSs positively affect innovation performance since knowledge acquired from users can be used to enhance process or to generate new products and services (Ku 2013). In this sense, SNSs is part of enterprises' eco-system where a wide flow of knowledge encourages the development of new innovative ideas (McEvily and Chakravarthy 2002; Schultze and Stabell 2004; Levy 2009; Hine et al. 2010).

Furthermore, two relevant entrepreneurial mind-sets arose from this analysis: (1) entrepreneurs' ability to create innovations; and (2) entrepreneurs' willing to make solid collaborations with their digital eco-system (Audretsch et al. 2016; Malerba 2010; Hanna et al. 2011; Hirsch-Kreinsen and Schwinge 2014).

In sum remarking the intensive use of knowledge, enterprises are motivated to break out routines and generate innovation. Hence entrepreneurs carry out new combination of such knowledge, adopting an experiential and collaborative approach. This approach calls for a process of discovery, realisation, and exploitation of new ideas (Garretson 2008; Chesbrough 2011).

\section{Concluding remarks}

Drawing practical implications from this study, we retain that an understanding of the relevance of SNSs as IT-based sources may drive policymakers and other agencies supporting SMEs. Our results show that the SNSs have a positive role in affecting both absorptive capacity and innovation performance of SMEs. In this sense, it can be implied that SMEs are aware of the need to implement an online sustainable strategy for achieving global strategic purposes. This strategy should be developed with limited investments, creating a solid and extensive network with enterprises' stakeholders. A partnership with 
another business andlor a public institution, as well as with customers can be a way forward. Overall, one of the goals of an enterprise is to create innovation minimizing costs and effort. Therefore, enterprises are actively cooperating with the external environment in order to achieve global innovation performances that can enhance their value creation and productivity as well. In line with this, innovation process is greatly focused on userslconsumers. Enterprises tend not just attract consumers to sell products but also to cooperate with them so as to generate innovations. In turns, starting from the growing innovation user-oriented approach, scholars might be inspired to develop further research and extend the present study. In fact we shall recognise that this research is subject to a number of limitations and that the results arising from it are to be taken carefully. For example, we could not analyse how the use of SNSs among employees can encourage them in creating new products or services. Future research, starting from a customer's oriented approach, it would be worthwhile to investigate how customers are assuming a central role in R\&D activities. Moreover, we suggest that other scholars expand on this study and analyse closely SMEs, building interesting and valuable case studies to present a more comprehensive picture of how SNSs may support the innovation process. Future research on small samples may also wish to look into online dimensions that may play a role in the innovation process and knowledge management. Along this, studies on dynamic entrepreneurship can be analysed on the lens of the digital, virtual market. Finally, as the virtual environment can play a focal role for enhancing innovations bolstering technology transfer and international cooperation for both knowledge and labour-intensive enterprises, further studies can go more in depth comparing the differences in regards to results and performances achieved by those two kinds of enterprises.

Acknowledgments Thanks to Professor Robert Smith from the University of the West of Scotland, who provided insights and expertise that greatly improved the manuscript.

Author's contribution The authors have jointly shared the present article. Nevertheless, Veronica Scuotto authored the methodology part; Manlio Del Giudice wrote the theoretical framework, and Elias G. Carayannis authored the discussion and conclusion. All three authors have equally shared the concluding remarks.

Open Access This article is distributed under the terms of the Creative Commons Attribution 4.0 International License (http://creativecommons.org/licenses/by/4.0/), which permits unrestricted use, distribution, and reproduction in any medium, provided you give appropriate credit to the original author(s) and the source, provide a link to the Creative Commons license, and indicate if changes were made.

\section{References}

Aboelmaged, M. G. (2014). Linking operations performance to knowledge management capability: The mediating role of innovation performance. Production Planning \& Control, 25(1), 44-58.

Adler, P., \& Shenhar, A. (1990). Adapting your technological base: The organizational challenge. Sloan Management Review, 32(1), 25-37.

Ahuja, G. (2000). Collaboration networks, structural holes, and innovation: A longitudinal study. Administrative Science Quarterly, 45(3), 425-455.

Ahuja, G., \& Morris Lampert, C. (2001). Entrepreneurship in the large corporation: A longitudinal study of how established firms create breakthrough inventions. Strategic Management Journal, 22(6-7), 521-543.

Amy, K., \& Poston, B. (2013). Social media and product —early adopters reaping benefits amidst Challenge and Uncertainty. Kalypso white paper. Retrieved from http://kalypso.com/downloads/insights/ Kalypso_Social_Media_and_Product_Innovation_1.pdf. Accessed 10 June 2014. 
Arts, S., \& Veugelers, R. (2015). Technology familiarity, recombinant novelty, and breakthrough invention. Industrial and Corporate Change, 24(6), 1215-1246.

AUB Observatory. (2014). In G. Corbetta, A. Minichilli, \& F. Quarato (Eds.), Executive summary (VI ed.). Cattedra AIdAF-Milan: Albert Falck, Strategia delle Aziende Familiari, Bocconi University.

Audretsch, D. B., Kuratko, D. F., \& Link, A. N. (2015). Making sense of the elusive paradigm of entrepreneurship. Small Business Economics, 45(4), 703-712.

Audretsch, D. B., Kuratko, D. F., \& Link, A. N. (2016). Dynamic entrepreneurship and technology-based innovation. Journal of Evolutionary Economics, 26, 603-620.

Audretsch, D. B., Lehmann, E. E., \& Wright, M. (2014). Technology transfer in a global economy. The Journal of Technology Transfer, 39(3), 301-312.

Berghman, L., Matthysens, P., \& Vandenbempt, K. (2006). Building competences for new customer value creation: an exploratory study. Industrial Marketing Management, 35(8), 961-973.

Berinato, S. (2010). Six ways to find value in Twitter's noise. Harvard Business Review, 88(6), 34-35.

Betz, F., Carayannis, E., Jetter, A., Min, W., Phillips, F., \& Shin, D. W. (2016). Modeling an innovation intermediary system within a helix. Journal of the Knowledge Economy, 7(2), 587-599.

Bharati, P., Zhang, C., \& Chaudhury, A. (2013). Social Media assimilation in firms: Investigating the roles of absorptive capacity and institutional pressures. Information Systems Frontiers. doi:10.1007/s10796013-9433-x.

Blackler, F. (1995). Knowledge, knowledge work and organizations: An overview and interpretations. Organization Studies, 16(6), 1021-1046.

Boyd, D., \& Ellison, N. (2008). Social network sites: Definition, history, and scholarship. Journal of Computer Mediated Communication, 13(1), 210-230.

Bryman, A. (2015). Social research methods. Oxford: Oxford University Press.

Byrne, B. M. (2013). Structural equation modelling with AMOS: Basic concepts, applications, and programming. London: Taylor \& Francis.

Campanella, F., Del Giudice, M., \& Della Peruta, M. R. (2013). The role of information in the credit relationship. Journal of Innovation and Entrepreneurship, 2(17), 1-16.

Campbell, D. F., Carayannis, E. G., \& Rehman, S. S. (2015). Quadruple helix structures of quality of democracy in innovation systems: The USA, OECD countries, and EU member countries in global comparison. Journal of the Knowledge Economy, 6(3), 467-493.

Carayannis, E. G. (2015). Innovation, technology, and knowledge management (forthcoming).

Carayannis, E. G., \& Alexander, J. (1999). Winning by co-opeting in strategic government-universityindustry R\&D partnerships: The power of complex, dynamic knowledge networks. The Journal of Technology Transfer, 24(2-3), 197-210.

Carayannis, E. G., Depeige, A., \& Sindakis, S. (2014a). Dynamics of ultra-organizational co-opetition and circuits of knowledge: A knowledge-based view of value ecology. Journal of Knowledge Management, $18(5), 1020-1035$.

Carayannis, E. G., Dubina, I. N., \& Ilinova, A. A. (2015a). Licensing in the context of entrepreneurial university activity: An empirical evidence and a theoretical model. Journal of the Knowledge Economy, 6(1), 1-12.

Carayannis, E. G., Grigoroudis, E., Sindakis, S., \& Walter, C. (2014b). Business model innovation as antecedent of sustainable enterprise excellence and resilience. Journal of the Knowledge Economy, $5(3), 440-463$.

Carayannis, E. G., Meissner, D., \& Edelkina, A. (2015b). Targeted innovation policy and practice intelligence (TIP2E): Concepts and implications for theory, policy and practice. The Journal of Technology Transfer, 1-25. doi:10.1007/s10961-015-9433-8.

Carayannis, E. G., \& Rakhmatullin, R. (2014). The quadruple/quintuple innovation helixes and smart specialisation strategies for sustainable and inclusive growth in Europe and beyond. Journal of the Knowledge Economy, 5(2), 212-239.

Carayannis, E. G., Sindakis, S., \& Walter, C. (2015c). Business model innovation as lever of organizational sustainability. The Journal of Technology Transfer, 40(1), 85-104.

Casaló, L. V., Flavián, C., \& Guinalíu, M. (2010). Determinants of the intention to participate in firm-hosted online travel communities and effects on consumer behavioural intentions. Tourism Management, 31(6), 898-911.

Chalkiti, K., \& Sigala, M. (2008). Information sharing and knowledge creation in online forums: The case of the Greek online forum 'DIALOGOI'. Current Issues in Tourism, 11(5), 381-406.

Chesbrough, H. W. (2011). Open services innovation-rethinking your business to grow and compete in a new era. Boston: Harvard Business School.

Chesbrough, H., \& Crowther, A. K. (2006). Beyond high tech: Early adopters of open innovation in other industries. $R \& D$ Management, 36(3), 229-236. 
Coccia, M. (2008). Spatial mobility of knowledge transfer and absorptive capacity: Analysis and measurement of the impact within the geoeconomic space. The Journal of Technology Transfer, 33, 105. doi:10.1007/s10961-007-9032-4.

Cohen, W. M., \& Levinthal, D. A. (1990). Absorptive capacity: A new perspective on learning and innovation. Administrative Science Quarterly, 35(1), 128-152.

Culnan, M. J., Patrick, J. M., \& Zubillaga, J. J. (2010). How large U.S. company can use Twitter and other social media to gain business value. MIS Quarterly Executive, 9(4), 243-259.

Damirchi, Q. V., \& Rahimi, G. (2011). Design a conceptual ERP model for small and medium enterprises of Iran. Contemporary Research in Business, 3(5), 850-860.

Decarolis, D. M., \& Deeds, D. L. (1999). The impact of stocks and flows of organizational knowledge on firm performance: An empirical investigation of the biotechnology industry. Strategic Management Journal, 20(1), 953-968.

Del Giudice, M., Della Peruta, M., \& Scuotto, V. (2014). Student entrepreneurship, creativity and success. How much does knowledge heterogeneity really matter? Journal International Entrepreneurship and Management. doi:10.1504/IJEIM.2014.062789.

Del Giudice, M., \& Maggioni, V. (2014). Managerial practices and operative directions of knowledge management within inter-firm networks: A global view. Journal of Knowledge Management, 18(5), 841-846.

Del Giudice, M., \& Straub, D. (2011). Editor's comments: IT and entrepreneurism: An on-again, off-again love affair or a marriage? MIS Quarterly, 35(4), iii-viii.

Dev, C. S., Buschman, J. D., \& Bowen, J. T. (2010). Hospitality marketing: A retrospective analysis (1960-2010) and predictions (2010-2020). Cornell Hospitality Quarterly, 51(4), 459-469.

Dholakia, U. M., \& Durham, E. (2010). One café chain's Facebook experiment. Harvard Business Review, $88(33), 26$.

Duncan, R. B. (1972). Characteristics of organizational environments and perceived environmental uncertainty. Administrative of Management Review, 17, 313-327.

Fisher, E., \& Reuber, A. R. (2011). Social interaction via new social media: (How) can interactions on Twitter affect effectual thinking and behaviour? Journal of Business Venturing, 26, 1-28.

Fosfuri, A., \& Tribó, J. A. (2008). Exploring the antecedents of potential absorptive capacity and its impact on innovation performance. Omega, 36(2), 173-187.

Garretson, R. (2008) Future tense: The global CMO, [online]. http://graphics.eiu.com/upload/Google\% 20Text.pdf. Accessed 12 Oct 2014.

Gopalani, A., \& Shick, K. (2011). The service-enabled customer experience: a jump-start to competitive advantage. Journal of Business Strategy, 32(3), 4-12.

Gronroos, C., \& Ravald, A. (2011). Service as business logic: Implications for value creation and marketing. Journal of Service Management, 22(1), 5-22.

Hanna, R., Rohm, A., \& Crittenden, V. L. (2011). We're all connected: The power of the social media ecosystem. Business Horizons, 54, 265-273.

Hannu, K., Jari, J., \& Jaani, V. (2010). Social media use and potential in business to business companies' innovation. International Journal of Ambient Computing and Intelligence (IJACI), 5(1), 228-236.

Hargadon, A. (2003). How breakthroughs happen: The surprising truth about how companies innovate. Harvard Business Press.

Hine, D. C., Parker, R., \& Ireland, D. (2010). The knowledge exchange intermediary as service provider: A discussion and an Australian case. Service Industries Journal, 30(5), 713-729.

Hirsch-Kreinsen, H., \& Schwinge, I. (2014). Knowledge-intensive entrepreneurship in low-tech industries. Cheltenham: Edward Elgar Publishing.

Hobday, M. (1995). East Asian latecomer firms: Learning the technology of electronics. World Development, 23(7), 1171-1193.

Hussinger, K. (2012). Absorptive capacity and post-acquisition inventor productivity. The Journal of Technology Transfer, 37, 490. doi:10.1007/s10961-010-9199-y.

Huy, Q. N. (2012). Emotions in strategic organization: Opportunities for impactful research. Strategic Organization, 10, 240-247.

Hvass, K. A., \& Munar, A. M. (2012). The take-off of social media in tourism. Journal of Vacation Marketing, 18, 93-103.

Jansen, J. J., Van Den Bosch, F. A., \& Volberda, H. W. (2005). Managing potential and realized absorptive capacity: How do organizational antecedents matter? Academy of Management Journal, 48(6), 999-1015.

Jardim-Goncalves, R., Popplewell, K., \& Grilo, A. (2012). Sustainable interoperability: The future of Internet based industrial enterprises. Computers in Industry, 63(8), 731-738. 
Kaplan, A., \& Haenlein, M. (2010). Users of the world, unite! The challenges and opportunities of social media. Business Horizons, 53(1), 59-68.

Kietzmann, J. H., Hermkens, K., McCarthy, I. P., \& Silvestre, B. S. (2011). Social media? Get serious! Understanding the functional building blocks of social media. Business Horizons, 54, 241-251.

Kim, L. (2004). The multifaceted evolution of Korean technological capabilities and its implications for contemporary policy. Oxford Development Studies, 32(3), 341-363.

Kozinets, R., de Valck, C., Wojnick, A., \& Wilner, S. (2010). Networked narratives: Understanding wordof- mouth marketing in online communities. Journal of Marketing, 74, 71-89.

$\mathrm{Ku}$, E. C. S. (2013). Putting forth marketing competencies strength with collaborating partners in the hotel industry. Service Business, 8(4), 679-697.

Lane, P. J., Koka, B., \& Pathak, S. (2006). The reification of absorptive capacity: A critical review and rejuvenation of the construct. Academy of Management Review, 31(4), 833-863.

Lane, P. J., \& Lubatkin, M. (1998). Relative absorptive capacity and interorganizational learning. Strategic Management Journal, 19(5), 461-477.

Laursen, K., \& Salter, A. (2006). Open for innovation: The role of openness in explaining innovation performance among U.K. manufacturing firms. Strategic Management Journal, 27(2), 131-150.

Levy, M. (2009). Web 2.0 implications on knowledge management. Journal of Knowledge Management, 13(1), 120-134.

Leyden, D. P., \& Link, A. N. (2015). Toward a theory of the entrepreneurial process. Small Business Economics, 2015(44), 475-484.

Liao, T., \& Yu, C. J. (2013). The impact of local linkages, international linkages, and absorptive capacity on innovation for foreign firms operating in an emerging economy. The Journal of Technology Transfer, 38, 809. doi:10.1007/s10961-012-9265-8.

Lichtenthaler, U. (2009). Absorptive capacity, environmental turbulence, and the complementarity of organizational learning processes. Academy of Management Journal, 52(4), 822-846.

Likert, R. (1932). A technique for the measurement of attitudes. Archives of Psychology, 22(14), 55-80.

Lohmöller, J. B. (1989). Latent variables path modelling with partial least squares. Heidelberg: PhysicaVerlag.

Lopez-Nicolas, C., \& Soto-Acosta, P. (2010). Analyzing ICT adoption and use effects on knowledge creation: An empirical investigation in SMEs. International Journal of Information Management, $30(6), 521-528$.

Malerba, F. (2010). Knowledge intensive entrepreneurship and innovation systems: Evidence from Europe. Abingdon: Routledge.

Mansfield, E. (1986). Patents and innovation: An empirical study. The Economics Management Science, 32(2), 173-181.

March, J. G., \& Herbert, A. S. (1958). Organizations. New York: Wiley.

McAlexander, J. H., Schouten, J. W., \& Harold, F. K. (2002). Building brand community. Journal of Marketing, 66(1), 38-54.

Nicotra, M., Romano, M., \& Del Giudice, M. (2014). The evolution dynamic of a cluster knowledge network: The role of firms' absorptive capacity. Journal of the Knowledge Economy, 5(1), 70-93.

McEvily, S., \& Chakravarthy, B. (2002). The persistence of knowledge-based advantage: an empirical test for product performance and technological knowledge. Strategic Management Journal, 23(1), 285-305.

McKelvey, M., \& Lassen, A. H. (2013). Knowledge intensive entrepreneurship: Engaging, learning and evaluating venture creation. Cheltenham: Edward Elgar Publishing.

Metters, R., \& Walton, S. (2007). Strategic supply chain choices for multi-channel internet retailers. Service Business, 1(4), 317-331.

Muniz, A. M., \& O'Guinn, T. C. (2001). Brand community. Journal of Consumer Research, 27(4), 412-432.

Nonaka, I., \& Takeuchi, H. (1995). The knowledge creating company: How Japanese companies create the dynamics of innovation. New York: Oxford University Press.

Palacios-Marqués, D., Soto-Acosta, P., \& Merigó, J. M. (2015a). Online social networks as an enabler of innovation in organizations. Management Decision, 53(9), 1906-1920.

Palacios-Marqués, D., Soto-Acosta, P., \& Merigó, J. M. (2015b). Analysing the effects of technological, organizational and competition factors on Web knowledge exchange in SMEs. Telematics and Informatics, 32(1), 23-32.

Pechlaner, H., \& Bachinger, M. (2010). Knowledge networks of innovative businesses: An explorative study in the region of Ingolstadt. Service Industries Journal, 10(10), 1737-1756.

Porter, M. E. (2001). Strategy and the internet. Harvard Business Review, 79(2), 62-78.

Roberts, N., Galluch, P. S., Dinger, M., \& Grover, V. (2012). Absorptive capacity and information system research: Review, synthesis and directions for future research. MIS Quarterly, 35(4), 1-24. 
Rogers, E. M. (2003). Diffusion of innovations (5th ed.). New York: Free Press.

Rosenkopf, L., \& Nerkar, A. (2001). Beyond local search: Boundary-spanning, exploration, and impact in the optical disk industry. Strategic Management Journal, 22(4), 287-306.

Schmallegger, D., \& Carson, D. (2008). Blogs in tourism: Changing approaches to information exchange". Journal of Vacation Marketing, 14, 99-110.

Schultze, U., \& Stabell, Ch. (2004). Knowing what you don't know? Discourses and contradictions in knowledge management research. Journal of Management Studies, 41(1), 549-573.

Schumpeter, J. A. (1934). The theory of economic development: An inquiry into profits, capital, credit, interest, and the business cycle (Vol. 55). Piscataway: Transaction Publishers.

Scuotto, V. (2014). Improving absorptive capacity through social media networks for firms' innovativeness. Paper presented at the 9th European Conference on Innovation and Entrepreneurship (ECIE 2014). http://academic-conferences.org/ecie/ecie2014/ecie14-home.htm.

Scuotto, V. (2015). The effect of social networking sites and absorptive capacity on firms' innovativeness. Paper was presented at the International Conference on Marketing, Business and Management at Beijing Union University in Beijing, China.

Scuotto, V., Ferraris, A., \& Bresciani, S. (2016a). Internet of things: Applications and challenges in smart cities. A case study of IBM smart city projects. Business Process Management Journal, 22(2), 357-367.

Scuotto, V., Guo, X., \& Xue, W. (2015). Exploring the use of social networking sites in banking services: Evidence from China. Paper was presented at the 60th Annual ICSB World Conference in Dubai, UAE. http://www.icsb2015.org/.

Scuotto, V., \& Morellato, M. (2013). Entrepreneurial knowledge and digital competence: Keys to success for student entrepreneurship. Journal of the Knowledge Economy. doi:10.1007/s13132-013-0155-6.

Scuotto, V., Santoro, G., Papa, A., \& Carayannis, E. (2016b). Users generated ideas via social media networks: Based on OI model. In Conference Proceedings, EuroMed Press, ISBN: 978-9963-711-43-7.

Shih, K. H., Chang, C. J., \& Li, B. (2010). Assessing knowledge creation and intellectual capital in the banking industry. Journal of Intellectual Capital, 11(1), 74-89.

Sigala, M., \& Chalkiti, K. (2012). Knowledge management and web 2.0: Preliminary findings from the greek tourism industry. In M. Sigala, E. Christou, \& U. Gretzel (Eds.), Web 2.0 in travel, tourism and hospitality: Theory, practice and cases. Farnham: Ashgate Publishers.

Soto-Acosta, P., Popa, S., \& Palacios-Marqués, D. (2015). E-business, organizational innovation and firm performance in manufacturing SMEs: An empirical study in Spain. Technological and Economic Development of Economy. doi:10.3846/20294913.2015.1074126.

Stelzner, M. A. (2013). Social media marketing industry report: How marketers are using social media to grow their businesses, [online] social media examiner. http://www.socialmediaexaminer.com/ SocialMediaMarketingIndustryReport2013.pdf. Accessed 12 Jun 2015.

Teirlinck, P., \& Spithoven, A. (2012). Fostering industry-science cooperation through public funding: Differences between universities and public research centres. The Journal of Technology Transfer, 37(5), 676-695.

Tenehaus, M., Mauger, E., \& Guinot, C. (2010). Use of ULS-SEM and PLS-SEM to measure a group effect in a regression model relating two blocks of binary variables. In V. Esposito Vinzi, W. Chin, J. Henseler, \& H. Wang (Eds.), Partial least squares: Concepts, methods and applications, computational statistics handbook series. Berlin: Springer.

Trusov, M., Bucklin, R., \& Pauwels, K. (2009). Effect of word-of-mouth versus traditional marketing: Findings from an Internet social networking sites. Journal of Marketing, 73, 90-102.

Tussyadiah, I., \& Zach, F. (2013). Social media strategy and capacity for consumer co-creation among destination marketing organizations. In L. Cantoni \& Z. Xiang (Eds.), Information and communication technologies in tourism 2013. Berlin: Springer.

Utterback, J. M. (1974). Innovation and the diffusion of technology. Science, 183(4125), 620-626.

Wang, D., \& Scuotto, V. (2012). Innovation, second mover and network system. Symphonya Emerging Issues in Management, 2, 66-76.

Weinberger, D. (2007). Everything is miscellaneous. The power of the new digital disorder.,New York: Times Books.

Weston, J., Ratle, F., \& Collobert, R. (2008). Deep learning via semi-supervised embedding. In Proceedings of the 25th International Conference on Machine Learning (pp. 1168-1175).

Zahra, S. A., \& George, G. (2002). Absorptive capacity: A review, reconceptualization, and extension. Academy of Management Review, 27(2), 185-203. 